\title{
Effects of protein and/or amino-acid levels on reproductive performance and metabolic profile of lactating sows
}

\author{
AF Falaschini ${ }^{1}$, LA Volpelli ${ }^{2}$, MF Trombetta ${ }^{1}$ \\ 1 Dipartimento Biotecnologie Agrarie ed Ambientali, Via Brecce Bianche, 60131 Ancona; \\ 2 Dipartimento di Scienze della Produzione Animale, Via S Mauro, 2, 33010 Pagnacco UD, Italy
}

(Received 4 December 1992; accepted 3 August 1993)

\begin{abstract}
Summary - Three groups of 12 sows (high-productivity Goland hybrids) were fed from the 106th day of gestation to the end of lactation ( $27 \pm 3$ d) one of 3 diets: $C_{1}, L_{1}$, LPS $_{1}$ (experiment 1). The diets differed in protein levels (CP (\%DM): 16.7; 13.4; 14.1, respectively) and amino-acid content (lysine (\%DM): $0.87 ; 0.48 ; 0.86 ;$ methionine + cystine (\%DM): $0.57 ; 0.42 ; 0.56$; threonine (\%DM): $0.70 ; 0.53 ; 0.53 ;$ tryptophan (\%DM): $0.20 ; 0.12 ; 0.20)$. In a second experiment, 4 groups of 11 sows were fed one of 4 diets (experiment 2 ): $\mathrm{C}_{2}$, LP 2 , LPPS, LPS $(C P(\% D M): 17.2 ; 11.9 ; 13.3 ; 13.6$, respectively; lysine (\%DM): $0.77 ; 0.39 ; 0.54 ; 0.76$; methionine + cystine (\%DM): $0.59 ; 0.45 ; 0.52$; 0.55 ; threonine (\%DM): $0.67 ; 0.45 ; 0.56 ; 0.66$; tryptophan $(\% \mathrm{DM}): 0.20 ; 0.12 ; 0.17 ; 0.20$, respectively). The LPS ${ }_{1}$ diet was supplemented with the synthetic amino acids, lysine, methionine, tryptophan, and LPPS and LPS2 were also supplemented with threonine. The different diets had no significant effects on sow performance and litter productivity. Low-protein and amino-acidsupplemented diets significantly reduced both blood (experiment $1: C_{1} 30.3 ;$ LP $_{1} 28.0 ;$ LPS $_{1} 22.1$ $\mathrm{mg} / \mathrm{dl}$; experiment 2: $\mathrm{C}_{2} 36.5 ; \mathrm{LP}_{2} 31.4$; LPPS 30.8; $\mathrm{LPS}_{2} 21.3 \mathrm{mg} / \mathrm{dl}$ ) and milk urea values (experiment 2: $C_{2} 20 ; L P_{2} 13$; LPPS 9; $L P S_{2} 10 \mathrm{mg} / \mathrm{dl}$ ), which indicates a reduction in protein catabolism.
\end{abstract}

sow / dietary protein / amino acid / blood / milk

Résumé - Réalisation de 2 expériences pour vérifier la possibilité de réduire la teneur en protéines chez la truie en lactation. Dans la première expérience, 3 groupes de 12 truies (hybrides Goland fortes productrices) ont été alimentées avec des régimes qui avaient des taux de protéines (MAT \% MS : $\left.C_{1} 16,7 ; L P, 13,4 ; L P S, 14,1\right)$ et d'acides aminés différents (lysine \% MS : $C_{1} 0,87 ; L P, 0,48 ; L P S_{1} 0,86 ;$ méthionine + cystine \% MS : $C_{1} 0,57 ; L P, 0,42 ; L P S$, 0,56 ; thréonine \% MS : $C_{1} 0,70 ; L P_{1} 0,53 ; L P S_{1} 0,53 ;$ tryptophane \% MS: $C_{1} 0,20, L P_{1}$ 0,12 ; LPS, 0,20) à partir du $106^{\circ} j$ de gestation jusqu'à la fin de la lactation $(27 \pm 3 j$ ). Dans la deuxième expérience, 4 groupes de 11 truies recevaient 4 régimes expérimentaux (MAT \% MS : $C_{2} 17,2 ; L P_{2} 11,9 ;$ LPPS 13,$3 ; L P S_{2} 13,6$-lysine \% MS; $C_{2} 0,77 ; L P_{2} 0,39 ;$ LPPS 0,54 ; $L P S_{2} 0,76$ méthionine + cystine \% MS : $C_{2} 0,59 ; L P_{2} 0,45 ;$ LPPS 0,$52 ; L P S_{2} 0,55 ;$ thréonine \% MS : $C_{2} 0,67 ; L P_{2} 0,45 ;$ LPPS 0,$56 ; L P S_{2} 0,66 ;$ tryptophane \% MS : $C_{2} 0,20 ; L P_{2} 0,12, L P P S$ 0,$\left.17 ; L_{2} P S_{2} 0,20\right)$. Les régimes LPS, LPPS et LPS2 étaient supplémentés à l'aide d'acides aminés 
industriels. Pendant les 2 cycles reproductifs suivants, on a évalué les performances reproductives de la truie et productives des porcelets, le profil métabolique de la truie; dans la deuxième expérience, on a évalué la composition du lait produit. Les régimes administrés n'ont pas entrainé des variations significatives des performances reproductives de la truie et productives des porcelets, qui ont maintenu de bons niveaux $(1,1$ insémination par gestation ; $2000 \mathrm{~g} / \mathrm{j}$ de croissance de la portée). De plus, la réduction du taux des protéines et la supplémentation en ăcides aminés ont procuré un abaissement de la teneur en urée dans le sang (1re expérience : $C_{1}$ 30,$3 ; L P_{1} 28 ; L P S_{1} 22,1 \mathrm{mg} / \mathrm{dl}-2^{\circ}$ expérience $C_{2} 36,5 ; L P_{2} 31,4 ;$ LPPS 30,$8 ;$ LPS $_{2}$ $21,3 \mathrm{mg} / \mathrm{dl}$ ) et dans le lait (2e expérience $C_{2} 20 ; L P_{2} 13 ;$ LPPS $9 ; L P S_{2} 10 \mathrm{mg} / \mathrm{dl}$ ), en raison d'une diminution du catabolisme des protéines. L'analyse du profil métabolique et de la composition du lait amène à considérer que les régimes à faible teneur en protéines et après supplémentation équilibrée en acides aminés améliorent l'état métabolique de la truie.

truie / protéine / acides aminés / sang / lait

\section{INTRODUCTION}

During the productive cycle of swine, the lactation period is characterized by very high nutrient requirements. The dietary protein level is of major importance in the sow's productive and reproductive performance (ie milk production and hence weight gain of litter, body condition, readiness to re-breed) (Mordenti and Sacchi, 1985; Duée and Henry, 1986; Dourmad et al, 1991). Studies of nitrogen requirements during lactation have mostly focused on total dietary protein levels (Greenhalgh et al, 1980; King and Dunkin, 1986; Brendemuhl et al, 1987), whereas studies of essential amino acids are fewer and mainly concentrate on lysine, which is generally considered the primary limiting amino acid (King, 1987; Zeman and Siske, 1987; Etienne et al, 1989; Dourmad et al, 1991). The amino-acid requirement levels are however being revised. Recent studies (Etienne et al, 1989; Whittemore, 1990; Dourmad et al, 1991) have demonstrated the need to adjust requirement levels to the improved productivity of sows today, with litters of 10-12 and maximum milk production of $10 \mathrm{~kg} / \mathrm{d}$ compared with litters of 8-9 and maximum milk production of $4-6 \mathrm{~kg} / \mathrm{d}$ of the sows used in earlier studies on amino-acid requirements.

Since essential amino acids are insufficient and not completely available in conven- tional feeds, lactating sows, like other animals with high nutritive requirements (ie in the first phases of growth), are frequently administered excessive amounts of protein (Gatel et al, 1991; Parisini et al, 1991). This method is criticized because the excess protein is utilized metabolically for energetic purposes, and because of its impact on the environment. Concern is mainly focused on the nitrogen content of excretions, which is directly related to the quality and quantity of the feed given. Notably, the concentration of nitrogen in the faeces (which accounts for about $30 \%$ of excreted $N$ ) depends on the digestibility of protein and therefore of the feed, whereas urinary nitrogen excretion $(70 \%$ of $N)$ is determined by the adaptability of nitrogen intake to the animal's requirements (Dourmad et al, 1989; Piva and Morlacchini, 1990; Gatel et al, 1991). The present availability of the complete range of pure amino acids (industrial or synthetic) makes it possible to form the amino-acid profile of a diet by providing the correct amount of essential amino acids without increasing dietary protein.

Following the study of Etienne et al (1989) and Dourmad et al (1991), high-production sows were used in experiments to determine the possibility of reducing the nitrogen content in the diet of the lactating sow. 


\section{MATERIALS AND METHODS}

Two successive trials on hybrid Goland sows were conducted on a commercial farm. During the research the animals were monitored for their reproductive performance on 2 parities, with a conventional replacement rate of about $25 \%$ of the subjects. On average, the sows in experiment 1 completed $1.9 \pm 0.7$ cycles and those in experiment $25.9 \pm 1.5$ cycles. During pregnancy $2.6-2.8 \mathrm{~kg} / \mathrm{d}$ of a conventional diet (G) was provided, depending on body condition score. Experi- mental diets started about $8 \mathrm{~d}$ before farrowing The animals were fed semi-ad libitum which, according to Batterham (1974), improves the utilization of amino-acid supplements. During the first week after farrowing the feed allowance was gradually increased to $6 \mathrm{~kg} / \mathrm{d}$. The composition of diets is reported in table l. The crude protein and amino acids were analysed, and the digestible energy was calculated. The differences in the protein content of LPS, LPPS and LPS LOt $_{2}$ due to amino-acid supplements were attributed to the industrial mixing of feed.

Table I. Experimental diet composition.

\begin{tabular}{|c|c|c|c|c|c|c|c|c|}
\hline \multirow[b]{2}{*}{ Diet } & \multirow[b]{2}{*}{$G$} & \multicolumn{3}{|c|}{ Experiment 1} & \multicolumn{4}{|c|}{ Experiment 2} \\
\hline & & $c_{1}$ & $L P_{1}$ & $L P S_{1}$ & $C_{2}$ & $L P_{2}$ & LPPS & $L P S_{2}$ \\
\hline Cassava & 5.0 & 15.0 & 20.0 & 20.0 & - & - & - & - \\
\hline Corn & 34.0 & 12.7 & 18.2 & 18.2 & 21.0 & 31.0 & 31.0 & 31.0 \\
\hline Barley & 21.0 & 10.0 & 10.0 & 10.0 & 14.5 & 16.5 & 16.5 & 16.5 \\
\hline Wheat & - & 10.0 & 13.0 & 13.0 & 10.0 & 10.0 & 10.0 & 10.0 \\
\hline Corn gluten meal & - & 10.0 & 10.0 & 10.0 & 10.0 & 10.0 & 10.0 & 10.0 \\
\hline Beet pulp & - & 6.0 & 5.0 & 5.0 & 10.0 & 10.0 & 10.0 & 10.0 \\
\hline Soybean (solvent extract) & 12.0 & 13.5 & - & - & 10.0 & - & - & - \\
\hline Wheat flour middlings & 7.0 & - & - & - & 5.0 & 8.0 & 8.0 & 8.0 \\
\hline Molasses & 3.0 & 5.0 & 5.0 & 5.0 & 5.0 & 5.0 & 5.0 & 5.0 \\
\hline Fullfat soybean & 3.0 & 8.0 & 7.0 & 7.0 & 5.0 & - & - & - \\
\hline Alfalfa hay & 10.0 & 3.0 & 5.0 & 5.0 & - & - & - & - \\
\hline Linseed meal & - & - & - & - & 3.0 & 3.0 & 3.0 & 3.0 \\
\hline Animal fat & - & 2.0 & 2.0 & 2.0 & 2.0 & 2.0 & 2.0 & 2.0 \\
\hline Dicalcium phosphate & 2.0 & 2.0 & 2.0 & 2.0 & 1.5 & 1.5 & 1.5 & 1.5 \\
\hline Calcium carbonate & 2.0 & 0.8 & 0.8 & 0.8 & 1.0 & 1.0 & 1.0 & 1.0 \\
\hline Trace elements + vitamins * & 1.0 & 2.0 & 2.0 & 2.0 & 2.0 & 2.0 & 2.0 & 2.0 \\
\hline L-Lysine $-\mathrm{HCl}{ }^{* *}$ & - & - & - & 0.37 & - & - & 0.15 & 0.35 \\
\hline DL-Methionine ** & - & - & _ & 0.13 & - & - & 0.06 & 0.09 \\
\hline L-Threonine ** & - & - & - & - & - & - & 0.10 & 0.20 \\
\hline L-Tryptophan ** & - & - & - & 0.075 & - & - & 0.04 & 0.07 \\
\hline \multicolumn{9}{|l|}{ Chemical analysis (DM) } \\
\hline Crude protein $(\%)$ & 16.76 & 16.67 & 13.41 & 14.10 & 17.20 & 11.89 & 13.28 & 13.60 \\
\hline Lysine & 0.80 & 0.87 & 0.48 & 0.86 & 0.77 & 0.39 & 0.54 & 0.76 \\
\hline Methionine + cystine & 0.48 & 0.57 & 0.42 & 0.56 & 0.59 & 0.45 & 0.52 & 0.55 \\
\hline Threonine & 0.66 & 0.70 & 0.53 & 0.53 & 0.67 & 0.45 & 0.56 & 0.66 \\
\hline Tryptophan & 0.18 & 0.20 & 0.12 & 0.20 & 0.20 & 0.12 & 0.17 & 0.20 \\
\hline $\mathrm{DE}(\mathrm{kcal} / \mathrm{kg})$ & 3360 & 3526 & 3496 & 3496 & 3636 & 3672 & 3674 & 3674 \\
\hline $\mathrm{DE} / \mathrm{CP}(\mathrm{kcal} / \mathrm{g})$ & 20 & 21 & 26 & 24 & 21 & 31 & 28 & 27 \\
\hline DE/Lysine (kcal/g) & 420 & 405 & 728 & 407 & 472 & 942 & 680 & 483 \\
\hline
\end{tabular}

* Supplementation per $\mathrm{kg}$ of diet: vitamin A $15000 \mathrm{IU}$; vitamin $\mathrm{D}_{3} 2000 \mathrm{IU}$; vitamin $\mathrm{B}_{1} 2 \mathrm{mg}$; vitamin $\mathrm{B}_{2} 6 \mathrm{mg}$; vitamin $B_{6} 2 \mathrm{mg}$; vitamin $B_{12} 0.01 \mathrm{mg}$; biotin $0.1 \mathrm{mg}$; vitamin E $10 \mathrm{mg}$; vitamin $\mathrm{K} 3 \mathrm{mg}$; vitamin $\mathrm{PP} 30 \mathrm{mg}$; D-pantothenic acid $11.5 \mathrm{mg}$; choline $400 \mathrm{mg}$; Mn $51 \mathrm{mg}$; Zn $67.2 \mathrm{mg}$; Fe $80 \mathrm{mg}$; Cu $25 \mathrm{mg}$; $1.7 \mathrm{mg}$; Co $2.16 \mathrm{mg}$; Se $0.1 \mathrm{mg}$. In experiment 2 feeds were supplemented with $1 \mathrm{~kg} / 100 \mathrm{~kg}$ bentonite (DM 89.54\%) containing: total ash $96.01 \%$, insoluble acid ash $75.51 \%$. "* Added after mixing diets $L P$, and $L P_{2}$. 


\section{Experiment 1}

The control group $\left(C_{1}\right)$ was given conventional feed, the second $\left(L P_{1}\right)$ a low-protein diet, and the third (LPS 1 ) a low-protein diet supplemented with lysine, methionine, and synthetic tryptophan to equal $C_{1}$ values. The following was recorded: (i) sow weight $8 \mathrm{~d}$ before farrowing and at weaning; (ii) intervals to next oestrus, conception and parturition; (iii) litter size at birth and weaning $(27 \pm$ $3 \mathrm{~d}$ ), and mortality numbers and causes; (iv) piglet weight $2 \mathrm{~d}$ after birth and at weaning. The metabolic profiles of blood samples collected from the jugular vein in the morning before feeding, on the day after farrowing and at weaning were analysed. The following parameters were analysed with Biochemia kits: urea; total protein; albumin; cholesterol; triglyceride; total lipids; and the enzymes GOT (aspartate-aminotransferase), GPT (alanine-aminotransferase), GGT ( $\gamma$-glutamil transferase). Kinetic tests were carried out at $25^{\circ} \mathrm{C}$. The broader application of this study was contrived to include variations of the parameters not directly linked to protein metabolism.

\section{Experiment 2}

Using the same methods as described above, 4 groups of 11 sows were given one of 4 diets: control feed $\left(C_{2}\right)$, low-protein feed $\left(\mathrm{LP}_{2}\right)$, lowprotein feed with intermediate amino-acid supplementation (LPPS), and low-protein feed supplemented with lysine, methionine, threonine and tryptophan to equal $\mathrm{C}_{2}$ values $\left(\mathrm{LPS}_{2}\right.$ ) (table I).

In addition to the productivity parameters studied in experiment 1 , the following points were analysed. The composition of milk obtained after parenteral injection of 30-40 IU oxytocin was analysed $2 d$ after farrowing and on the 12 th and 25 th $\mathrm{d}$ of lactation. The $\mathrm{pH}$ was determined on individual samples. Density, dry residue (lyophilization and successive drying), protein (Kjeldahl method), fat (Gerber method), and urea (enzymeconductimetric analysis by Bun-Analyzer 2, Beckman) were measured on a pool of 2 or 3 samples. in addition to the 2 blood samples taken as in experiment 1 , another was taken $8 d$ before farrowing to obtain reference values. NEFA (nonesterified fatty acid) analysis was also added to the tests reported above.

Data from the 2 experiments was interpreted separately by an analysis of variance, compa- ring the averages with Student's t-test; the 'cycle' factor originally introduced was subsquently excluded for its failure to cause significant effects on the variability of the parameters examined. Milk composition was calculated by a factorial scheme of analysis of variance of 4 diets $\times 3$ lactation stages. The statistical analysis of litter size and mortality was made by the $\chi^{\text {square-test. }}$

\section{RESULTS}

\section{Experiment 1}

Sow performance is reported in table II, and did not vary with the different diets; weaning-oestrus and weaning-conception intervals were optimum in all groups.

Litter size and weight at weaning (table III) were lower in the LP ${ }_{1}$ group, as well as at birth. Litter performance was unaffected by the low-protein diets and the weight gain was satisfactory $(2000 \mathrm{~g} / \mathrm{d})$.

The metabolic profile obtained from the blood samples collected at farrowing and weaning is reported in table IV. In the former, which was taken about $8 \mathrm{~d}$ after experimental feeding was started, total protein declined in the LP 1 group. In the samples taken at weaning, total protein was similar in the 3 groups, but albumin was notably lower $(P \leq 0.01)$ in LP $P_{1}$ sows $(3.0 \mathrm{~g} / 100 \mathrm{ml})$ than in the other 2 groups $\left(\mathrm{LPS}_{1}=3.4\right.$ and $\mathrm{C}_{1}=$ $3.3 \mathrm{~g} / 100 \mathrm{ml})$. Moreover, urea values were significantly lower $(P \leq 0.01)$ in the aminoacid-supplemented group LPS L $_{1}$ (22.1 $\mathrm{mg} / 100 \mathrm{ml})$ than in $\mathrm{C}_{1}(30.3 \mathrm{mg} / 100 \mathrm{ml})$ and $\mathrm{LP}_{1}(28.0 \mathrm{mg} / 100 \mathrm{ml})$.

\section{Experiment 2}

During this experiment the stock farm was affected by a high rate of piglet mortality, caused by the presence of many old sows with problems in milk production. 
Table II. Experiment 1: sow productive performance.

\begin{tabular}{|c|c|c|c|c|}
\hline Diet & $c_{1}$ & $L P_{1}$ & $L P S_{1}$ & $E M S$ a $(D F)$ \\
\hline No of subjects & 22 & 23 & 23 & - \\
\hline Initial weight $(\mathrm{kg})$ & 241.7 & 229.5 & 238.3 & - \\
\hline Weight loss (\%) & 22.4 & 22.0 & 20.7 & $36.56(65)$ \\
\hline Weaning-oestrus interval (d) & 5.3 & 5.0 & 5.7 & $12.59(63)$ \\
\hline Weaning-conception interval (d) & 7.3 & 11.3 & 8.6 & $262.78(62)$ \\
\hline No of matings & 1.1 & 1.2 & 1.1 & $0.34(62)$ \\
\hline Interpartum (d) & 149.3 & 152.6 & 146.7 & $202.46(61)$ \\
\hline
\end{tabular}

${ }^{*} \mathrm{EMS}=$ error mean square; $\mathrm{DF}=$ degrees of freedom.

Table III. Experiment 1: litter productive performance.

\begin{tabular}{lcccc}
\hline Diet & $C_{1}$ & $L P_{1}$ & $L P S_{1}$ & $\begin{array}{c}E M S \text { a } \\
(D F=65)\end{array}$ \\
\hline No of litters & 22 & 23 & 23 & - \\
No of born & 11.1 & 10.2 & 11.2 & 4.64 \\
No of born alive & 10.7 & 9.8 & 10.6 & 4.19 \\
Weight at 2 d (kg) & 1.74 & 1.76 & 1.68 & 0.06 \\
No of weaned & $9.9 \mathrm{c}$ & $8.7 \mathrm{~d}$ & $9.5 \mathrm{~cd}$ & 2.64 \\
Weight at weaning (kg) & $77.4 \mathrm{c}$ & $65.3 \mathrm{~d}$ & $73.7 \mathrm{~cd}$ & 207.13 \\
Weight gain (g/d) & 223 & 221 & 228 & 1.67 \\
& & & & \\
Mortality & & & & \\
Crushing (\%) & 5.2 & 6.7 & 9.9 & 94.65 \\
Other causes $\mathrm{b}(\%)$ & 2.6 & 2.8 & 2.5 & 27.74 \\
& & & & \\
\hline
\end{tabular}

a EMS = error mean square; DF = degrees of freedom; ${ }^{b}$ pathologies and malformation; different letters on the same line indicate significant differences of $P \leq 0.05$.

The data on productive performance is summarized in table $\mathrm{V}$. There were no statistically significant differences in reproductive parameters. Piglet performance (table VI) shows statistically significant differences only in weight $2 \mathrm{~d}$ after birth (higher in LPPS piglets). In regard to mortality by crushing, it seems correct to ascribe this to the causes mentioned above.
The composition of milk at different stages of lactation is represented in table VII. The protein level did not differ significantly. Variability was to a great extent absorbed by the effect of 'lactation stage' since, as expected, the time of collection causes significant differences for nearly all the parameters. The milk urea results were quite interesting. Compared with group $\mathrm{C}_{2}$ 
Table IV. Experiment 1: variations in the metabolic profile.

\begin{tabular}{|c|c|c|c|c|}
\hline Diet & $C_{1}$ & $L P_{1}$ & LPS, & $E M S$ a $(D F=60)$ \\
\hline \multicolumn{5}{|l|}{ Parturition } \\
\hline Total protein $(\mathrm{g} / \mathrm{dl})$ & $7.5 \mathrm{~b}$ & $7.0^{\mathrm{c}}$ & $7.5^{b}$ & 0.46 \\
\hline Urea $(\mathrm{mg} / \mathrm{dl})$ & 26.7 & 24.2 & 23.6 & 34.78 \\
\hline GGT (U/I) & $31.7^{b}$ & $24.7^{c}$ & $19.5^{c}$ & 110.12 \\
\hline Triglycerides $(\mathrm{mg} / \mathrm{dl})$ & $31.6 \mathrm{bc}$ & $28.6^{c} \mathrm{c}$ & $38.5^{\mathrm{b}}$ & 165.12 \\
\hline \multicolumn{5}{|l|}{ Weaning } \\
\hline Total protein $(\mathrm{g} / \mathrm{dl})$ & 6.6 & 6.9 & 6.4 & 0.79 \\
\hline Albumin $(\mathrm{g} / \mathrm{dl})$ & $3.3^{d}$ & $3.0^{\circ}$ & $3.4^{d}$ & 0.20 \\
\hline Urea (mg/dl) & $30.3^{d}$ & $28.0^{d}$ & $22.1^{\ominus}$ & 21.99 \\
\hline GGT $(\mathrm{U} / \mathrm{I})$ & $30.7 \mathrm{~d}$ & $23.3^{e}$ & 20.5 e & 87.58 \\
\hline Total lipids (mg/dl) & $432{ }^{\circ}$ & $528 \mathrm{~d}$ & 398 e & 20986.88 \\
\hline Cholesterol (mg/dl) & 77.00 & $94.8 \mathrm{~d}$ & 88.1 de & 339.95 \\
\hline
\end{tabular}

a EMS = error mean square; DF = degrees of freedom; different letters on the same line indicate significant differences of $b, c p \leq 0.05$ or $d, \theta P \leq 0.01$.

Table V. Experiment 2: sow productive performance.

\begin{tabular}{|c|c|c|c|c|c|}
\hline Diet & $c_{2}$ & $L P_{2}$ & LPPS & $L P S_{2}$ & $E M S$ a $(D F)$ \\
\hline No of subjects & 22 & 22 & 22 & 22 & - \\
\hline Initial weight (kg) & 242.0 & 265.0 & 261.9 & 262.4 & - \\
\hline Weight loss (\%) & 14.1 & 17.8 & 17.2 & 16.4 & $37.37(84)$ \\
\hline Weaning-oestrus interval (d) & 7.8 & 4.1 & 5.0 & 5.0 & $7.53(76)$ \\
\hline Weaning-conception interval (d) & 15.1 & 5.0 & 5.9 & 9.5 & $77.64(76)$ \\
\hline No of matings & 1.2 & 1.1 & 1.1 & 1.2 & $0.06(76)$ \\
\hline Interpartum (d) & 158.1 & 148.1 & 148.4 & 151.2 & $82.89(75)$ \\
\hline
\end{tabular}

a EMS = error square mean; DF = degrees of freedom.

values $(20 \mathrm{mg} / 100 \mathrm{mi})$, the level was lower in $L P_{2}$ sows $(13 \mathrm{mg})$ and even more so in LPPS and LPS $_{2}$ sows $(9$ and $10 \mathrm{mg}$, respectively). In table VIII the metabolic profile is analysed and subdivided into pre-parturition, parturition and weaning. Given the absence of specific literature on the subject, the first test was carried out independently of the diet provided. Differences in the protein pattern were only significant in the case of albumin, and were higher at parturition than at weaning. Parameters relative to the lipid pattern were influenced most at the time of collection. The total lipids and cholesterol levels rose from pre-parturition to weaning, whereas the increase of NEFA and the concurrent triglyceride decrease at parturition are explained by body fat mobi- 
Table VI. Experiment 2: litter productive performance.

\begin{tabular}{|c|c|c|c|c|c|}
\hline Diet & $C_{2}$ & $L P_{2}$ & LPPS & $L P S_{2}$ & $\begin{array}{c}E M S \text { a } \\
(D F=84)\end{array}$ \\
\hline No of litters & 22 & 22 & 22 & 22 & - \\
\hline No of born & 12.2 & 11.5 & 12.4 & 11.6 & 4.13 \\
\hline No of born alive & 11.1 & 10.6 & 11.3 & 10.6 & 4.40 \\
\hline Weight at $2 \mathrm{~d}(\mathrm{~kg})$ & $1.42 \mathrm{~d}$ & $1.44^{\mathrm{d}}$ & $1.60^{c}$ & $1.43^{d}$ & 0.05 \\
\hline No of weaned & 9.4 & 9.3 & 9.3 & 8.9 & 2.76 \\
\hline Litter weight at weaning $(\mathrm{kg})$ & 66.4 & 65.2 & 63.3 & 64.9 & 123.94 \\
\hline Weight gain $(g / d)$ & 206 & 209 & 197 & 219 & 815.74 \\
\hline \multicolumn{6}{|l|}{ Mortality } \\
\hline Crushing (\%) & $11.5 \mathrm{~cd}$ & $7.2 \mathrm{c}$ & $12.9 \mathrm{~d}$ & $8.1 \mathrm{~cd}$ & 80.23 \\
\hline Other causes b $(\%)$ & 3.6 & 6.0 & 5.2 & 5.9 & 61.13 \\
\hline
\end{tabular}

a $E M S$ = error mean square; DF = degrees of freedom; ${ }^{b}$ pathologies and malformations; different letters on the same line indicate significant differences of $P \leq 0.05$.

Table VII. Experiment 2: milk composition.

\begin{tabular}{|c|c|c|c|c|c|c|c|c|}
\hline \multirow[t]{2}{*}{ Factor } & \multicolumn{4}{|c|}{ Diet } & \multicolumn{3}{|c|}{ Lactation stage } & \multirow[t]{2}{*}{$E M S$ a $(D F)$} \\
\hline & $C_{2}$ & $L P_{2}$ & LPPS & $L P S_{2}$ & Parturition & 12 th $d$ & 25 th $d$ & \\
\hline $\mathrm{pH}$ & $6.90 \mathrm{~b}$ & $6.82 \mathrm{bc}$ & $6.73^{c}$ & $6.88^{c}$ & $6.42^{c}$ & $7.03^{b}$ & $7.05^{b}$ & $0.05(258)$ \\
\hline Density (g/) & $1.033^{\mathrm{e}}$ & $1.035^{d}$ & $1.033^{\theta}$ & $1.033^{e}$ & $1.036^{b}$ & $1.031^{c}$ & $1.033^{c}$ & $0.00(122)$ \\
\hline Dry residue (\%) & 20.00 & 19.06 & 19.84 & 19.65 & $21.66^{b}$ & $18.70^{\mathrm{c}}$ & $18.44^{c}$ & $2.86(107)$ \\
\hline Fat $(\%)$ & 8.48 & 7.58 & 8.09 & 9.08 & 8.55 & 8.08 & 8.14 & $4.64(107)$ \\
\hline Protein (\%) & 6.06 & 6.63 & 6.64 & 5.81 & $8.79 b$ & $4.84^{c}$ & $5.04^{c}$ & $1.93(107)$ \\
\hline Urea $(\mathrm{mg} / 100 \mathrm{ml})$ & $20^{b}$ & $13^{c}$ & 91 & $10 \mathrm{ct}$ & 12 & 13 & 13 & $19.79(55)$ \\
\hline
\end{tabular}

a EMS = error mean square; DF = degrees of freedom. Different letters on the same line indicate significant differences of $b, c, t P \leq 0.01$ and $d, \theta p \leq 0.05$.

lization due to higher energy requirements at the beginning of lactation. Among the enzyme pattern values, plasma GOT levels increased at parturition.

In table IX, the data is analysed as a function of the different experimental feeds, and subdivided between parturition and weaning. There were significant differences in the protein pattern at parturition in the albumin levels, which were decreased in LPS 2 sows, and in the urea levels, which were already lower in all low-protein groups, especially those supplemented with amino acids (LPPS and $\mathrm{LPS}_{2}$ ). All the parameters in the protein pattern varied at the end of lactation, and especially in the group LPS 2 , where protein and albumin approached $\mathrm{C}_{2}$ levels and urea was the lowest of all the experimental groups. 
Table VIII. Metabolic profile at different stages (data from experiment 2).

\begin{tabular}{|c|c|c|c|c|}
\hline & Preparturition & Parturition & Weaning & $E M S$ a $(D F=260)$ \\
\hline $\begin{array}{l}\text { Total protein (g/dl) } \\
\text { Albumin (g/dl) } \\
\text { Urea (mg/dl) } \\
\text { GGT (U/) } \\
\text { GOT (U/l) } \\
\text { GPT (U/) } \\
\text { Total lipids (mg/dl) b } \\
\text { Triglyceride (mg/dl) b } \\
\text { Cholesterol (mg/dl) } \\
\text { NEFA ( } \mu \text { Eq/l) b }\end{array}$ & $\begin{array}{c}7.9 \\
3.3^{\mathrm{cd}} \\
29.1 \\
18.0 \\
13.7^{\mathrm{d}} \\
16.4 \\
482^{\mathrm{d}} \\
73.9^{\mathrm{ct}} \\
56.2^{\mathrm{d}} \\
169 \mathrm{cdg}\end{array}$ & $\begin{array}{c}7.8 \\
3.4^{\mathrm{c}} \\
27.9 \\
18.6 \\
24.1^{\mathrm{c}} \\
15.6 \\
405^{\mathrm{e}} \\
30.9^{\mathrm{dh}} \\
54.5^{\mathrm{d}} \\
235^{\mathrm{cf}}\end{array}$ & $\begin{array}{c}8.0 \\
3.2^{\mathrm{d}} \\
29.9 \\
18.6 \\
14.7^{\mathrm{d}} \\
17.1^{-1} \\
601^{\mathrm{c}} \\
50.6^{\mathrm{dg}} \\
80.4^{\mathrm{c}} \\
166^{\mathrm{dh}}\end{array}$ & $\begin{array}{c}0.526 \\
0.24 \\
62.95 \\
47.35 \\
40.49 \\
20.19 \\
0.10 \\
0.39 \\
195.84 \\
0.33\end{array}$ \\
\hline
\end{tabular}

a $E M S=$ error mean square; $D F=$ degrees of freedom; $b$ calculation made on values transformed into In; different letters on the same line indicate significant differences of ode $P \leq 0.01$ or fgh $P \leq 0.05$.

Table IX. Experiment 2: metabolic profile variations.

\begin{tabular}{|c|c|c|c|c|c|}
\hline & $C_{2}$ & $L P_{2}$ & LPPS & $L P S_{2}$ & $E M S$ a $(D F=81)$ \\
\hline \multicolumn{6}{|l|}{ Parturition } \\
\hline Total protein $(\mathrm{g} / \mathrm{dl})$ & 7.8 & 7.6 & 7.9 & 7.9 & 0.49 \\
\hline Albumin $(g / d)$ & $3.5^{c}$ & $3.4^{\mathrm{c}}$ & $3.6^{\mathrm{c}}$ & $3.0 \mathrm{~d}$ & 0.22 \\
\hline Urea (mg/dl) & $36.5 \mathrm{c}$ & $29.7 d$ & $23.5^{\mathrm{e}}$ & $22.5 \mathrm{e}$ & 62.33 \\
\hline GGT $(U / N)$ & $16.2 \mathrm{~d}$ & $18.3 \mathrm{~cd}$ & $17.9 \mathrm{~cd}$ & $21.9 \mathrm{c}$ & 50.90 \\
\hline GPT (U/) & $13.4 \mathrm{dg}$ & $17.7 \mathrm{cf}$ & $15.7 \mathrm{dfg}$ & 15.3 dgh & 12.41 \\
\hline Total lipids (mg/dl) b & $333 \mathrm{~d}$ & $398 d$ & $496 \mathrm{c}$ & 384 d & 0.11 \\
\hline NEFA $(\mu \mathrm{E} /)^{\mathrm{b}}$ & $223 \mathrm{cdf}$ & $163 d g$ & 256 cdf & 297 of & 0.40 \\
\hline \multicolumn{6}{|l|}{ Weaning } \\
\hline Total protein $(\mathrm{g} / \mathrm{dl})$ & $8.0 \mathrm{cdig}$ & $7.7 \mathrm{dg}$ & $7.9 \mathrm{cdg}$ & 8.4 of & 0.62 \\
\hline Albumin $(g / d)$ & $3.3 \mathrm{cf}$ & $3.1 \mathrm{dg}$ & $2.8 \mathrm{dh}$ & $3.5 \mathrm{ct}$ & 0.17 \\
\hline Urea $(\mathrm{mg} / \mathrm{dl})$ & $36.5 \mathrm{c}$ & $31.4 \mathrm{~d}$ & $30.8 \mathrm{~d}$ & $21.3^{e}$ & 37.03 \\
\hline GOT $(U A)$ & $13.0 \mathrm{~d}$ & $14.6^{d}$ & $17.8 \mathrm{c}$ & $13.0 \mathrm{~d}$ & 10.22 \\
\hline GPT (U/) & $15.2 \mathrm{dg}$ & $18.2 \mathrm{cdf}$ & $19.2 \mathrm{cf}$ & $15.6 \mathrm{dg}$ & 17.33 \\
\hline Triglyceride $(\mathrm{mg} / \mathrm{dl})$ b & 43.1 & 40.7 & 64.1 & 53.3 & 0.58 \\
\hline NEFA $(\mu \mathrm{Eq} / 1) \mathrm{b}$ & $161 \mathrm{cdg}$ & $119 \mathrm{dg}$ & $118 d g$ & $304 \mathrm{cf}$ & 0.33 \\
\hline
\end{tabular}

a EMS = error mean square; DF = degrees of freedom; ${ }^{b}$ calculation made on values transformed into In; different letters on the same line indicate significant differences of ode $P \leq 0.01$ or fgh $P \leq 0.05$.

Lipid data shows increased NEFA values in $\mathrm{LPS}_{2}$ sows from parturition and especialiy at weaning. Finally, the values enzyme analysis at parturition increased in all experimental groups, whereas at the end of lactation the GGT and GPT values were similar in $\mathrm{C}_{2}$ and LPS $_{2}$ sows, and lower than those of the other 2 groups. 


\section{DISCUSSION}

In verifying the balance of amino-acid supplements, ileal digestibility was presumed to be $90 \%$, as proposed by Speer (cited by Dourmad et al, 1991). While in experiment 1 the supplement of lysine, and the methionine + cystine/lysine and threonine/lysine ratios were higher than those reported by Etienne et al (1989) and Dourmad et al (1991), in experiment 2 both lysine supplements and the amino-acid balance of diets $\mathrm{C}_{2}$ and $\mathrm{LPS}_{2}$ corresponded to the levels recommended by those authors. Diets $L P_{1}$, LP $_{2}$ and LPPS were unbalanced in the amino acids provided due to the elimination of soybean (solvent extract and full-fat) which reduced the lysine level.

In both experiments sow and litter performances were uninfluenced by the lowprotein diets and remained on very statisfactory levels (matings about 1.1; litter weight gain exceeding $2000 \mathrm{~g} / \mathrm{d}$ ). In group $\mathrm{C}_{2}$ the weaning-conception interval and inter-parturition were longer due to the presence of a sow with serious reproductive problems. The greater weight of LPPS piglets at $2 \mathrm{~d}$ is hardly attributable to the experimental diet, which had been administered for only $8 \mathrm{~d}$. Other researchers (Greenhalgh et al, 1980; King and Dunkin, 1986; Brendemuhl et al, 1987) observed decreased performance following dietary protein reduction, while in other trials (Zeman and Siske, 1987; Etienne et al, 1989) lysine supplements sustained them.

In the analysis of milk composition, the most notable aspect was urea, confirmed as reflecting the quality of dietary protein and amino-acid content to the animal's requirements. Unlike other researchers (Greenhalgh et al, 1980), a decreased in milk protein content after drastic dietary protein reduction with amino-acid supplements was not observed. The $\mathrm{pH}$ differences between the 4 groups are explained as in cows' milk (Bertoni, 1986) by the fact that the more acidic samples (LPPS and $L P_{2}$ ) also have higher protein levels.

Finally, the metabolic profile has provided interesting results which are similar in the 2 experiments. In the protein analysis, urea and albumin behaved in a remarkable way. Albumin tended to decrease at weaning, though moderately and without reaching deficient values, and only in lowprotein and low-amino-acid sows LP $_{1}, \mathrm{LP}_{2}$ and LPPS); it should be stressed that albumin, a transport serum protein, is synthesized in the liver depending on dietary aminoacid balance (Payne and Payne, 1987). The reduction of urea, which is widely considered to be inversely related to the biological value of dietary protein (Eggum, 1970; Malmlof and Askbrand, 1988), is an immediate indicator of nitrogen dietary decrease. This confirms the role of urea in reflecting the quality of dietary protein. The nitrogen values obtained in the 2 experiments, borne out by milk composition, indicate that these low-protein and low-amino-acid diets meet the lactating sow's metabolic requirements.

The results for the enzymes considered gave less precise indications, although it is to be emphasized that transaminase activity also makes up for the deficiency in nonessential amino acids. This may have occurred in experiment 2 , where the $\mathrm{LP}_{2}$ diet reached such low levels that it was insufficient in undifferentiated nitrogen, as already hypothesized by Etienne et al (1989) and Henry (1980). This explains the high GPT values of the $L P_{2}$ and LPPS groups and the total amino-acid supplement values being close to $\mathrm{C}_{2}$ data. The increase in GOT at parturition can be correlated with this function.

The higher energy values observed in $L P_{1}$ sows at weaning can be attributed to the higher energy: AA ratio of this diet.

The most important results from the energy profile came from the analysis of triglycerides and NEFA, which are reliable 
indicators of the energy utilization of diets. As noted above, the higher NEFA values observed in the LPS ${ }_{2}$ group at the end of lactation could be due to the lipomobilization necessary to sustain high milk production, which is made possible in hybrid sows by adequate amino-acid dietary levels.

Overall, the results obtained in these experiments indicate that the levels of undifferentiated protein currently fed to lactating sows $(15-17 \%$ as fed) can be substantially reduced to the levels tested in the present study. The small negative variations recorded with the $L P_{2}$ diet (crude protein $11.89 \%$ DM) suggest that the optimum undifferentiated protein level could be around $12.5 \% \mathrm{DM}$, with the addition of essential amino acids which have higher bioavailability than those contained in the usual protein sources. The absence of negative influences on sow and litter performances, and the improvement in the sow's metabolic condition (lower milk and blood urea) when the low-protein diet was partially or totally supplemented with amino acids, suggest that the intermediate levels (LPPS) of essential amino acids are sufficient. Despite the adverse opinion of Etienne et al (1989) regarding high-productivity sows, and the levels of lysine recommended by INRA 1989, this position seems to be supported by the fact that in the present experiments about $50 \%$ of the amino acids provided were synthetic.

\section{ACKNOWLEDGMENTS}

The authors gratefully acknowledge A Mordenti (University of Bologna) for critical evaluation of the manuscript and S Modena for editorial assistance. We thank $G$ Levan and $F$ Levan for assistance and availability on the pig farm. This research was carried out with contributions from the Italian Ministry of University and Scientific and Technological Research (MURST 60\%) and CRPA of Reggio Emilia (Italy).

\section{REFERENCES}

Batterham ES (1974) The effect of frequency of feeding on the utilization of free lysine by growing pigs. Br J Nutr 31, 237-242

Bertoni G (1986) Come l'alimentazione può modificare la composizione chimica del latte. Inf Zoot 33 (24), 20-24

Brendemuhl JH, Lewis AJ, Peo ER (1987) Effect of protein and energy intake by primiparous sows during lactation on sow and litter performance and sow serum thyroxine and urea concentrations. J Anim Sci 64, 1060-1069

Dourmad JY, Henri Y, Sève B (1989) Rejets azotés dans les déjections porcines : importance de l'alimentation. Porc Magazine 217, 24-28

Dourmad JY, Etienne M, Noblet J (1991) Contribution à l'étude des besoins en acids aminés de la truie en lactation. Joumées Rech Porcine en France 23, 61-68

Duée PH, Henry Y (1986) Alimentation azotée. In: Le porc et son élevage (JM Perez, P Mornet, A Rérat, eds) Maloine, Paris, 261-288

Eggum BO (1970) Blood urea measurement as a technique for assessing protein quality. $\mathrm{Br} J$ Nutr 24, 983-988

Etienne M, Noblet J, Dourmad JY, Fortune H (1989) Étude de besoin en lysine de truies en lactation. Journées Rech Porcine en France 21, 101-108

Fuller MF, Livingstone RM, Baird BA, Atkinson T (1979) The optimal amino-acid supplementation of barley for the growing pig. BrJ Nutr 41, 321-331

Gatel F, Bertin JM, Grosjean F (1991) Effet de la teneur en protéines et en acides aminés du régime sur excrétion azotée des porcs. Journées Rech Porcine en France 23, 8590

Greenhalgh JFD, Baird B, Grubb DA, Lightfoot AL, Smith $P$, Toplis $P$, Walker $N$, Williams $D$, Yeo ML (1980) Coordinated trials on the protein requirements of sow. 2. A comparision of 2 levels of dietary protein in gestation and 4 in lactation. Anim Prod 30, 395-406

Henry $Y(1980)$ Besoin azoté global du porc en croissance: résultats sur femelles et synthèse. Journées Rech Porcine en France 12, 183194

INRA (1989) L'alimentation des animaux monogastriques : porc, lapin, volailles. INRA Paris 
King $\mathrm{RH}$ (1987) Feeding sows during gestation and lactation. In: The JD Stewart memorial refresher course for veterinarians 95 , vol II Univ Sydney

King RH, Dunkin AC (1986) The effect of nutrition on the reproductive performance of first litter sows. 4 . The relative effects of energy and protein intakes during lactation on the performance of sow and their piglets. Anim Prod 43, 319-325

Malmlof K, Askbrand S (1988) A note on the potential of systematic plasma urea measurements as a basis for determining optimal supplementation levels of lysine and threonine in pig diets. Swedish J Agric Res 18, 191193

Mordenti A, Sacchi C (1985) Alimentazione ed efficienza riproduttiva della scrofa: ruoli delle proteine ed energia. Riv Suinicoltura 31 (6), 23-30
Parisini P, Martelli G, Mordenti A (1991) Ricerche sull'impiego di diete ipoproteiche integrate con lisina nella produzione del suino pesante. Riv Suinicoltura 32(5), 45-49

Payne JM, Payne S (1987) Components of the profile test. 3. Indicators of protein status. In: The Metabolic Profile Test. Oxford Univ Press, New York, 27-35

Piva G, Morlacchini M (1990) Riduzione dell'azione inquinante della deiezioni suine: importanza dell'alimentazione. Riv Suinicoltura 31 (6), 37-47

Whittermore CT (1990) Recenti innovazioni nell'allevamento e nell'alimentazione della scrofa. Riv Suinicoltura 9, 67-70

Zeman L, Siske V (1987) The effect of a reduction of crude protein levels in isolysine mixture for sows on the results of reproduction. Biol Chem Vet (Praha) 29, 43-51 